\title{
Subglacial drilling at Black Rapids Glacier, Alaska, U.S.A.: drilling method and sample descriptions
}

\author{
M. Truffer, ${ }^{1}$ R. J. Motyka, ${ }^{1}$ W. D. Harrison, ${ }^{1}$ K. A. Echelmeyer, ${ }^{1}$ B. Fisk, ${ }^{2}$ S. Tulaczyk ${ }^{3}$ \\ ${ }^{1}$ Geophysical Institute, University of Alaska Fairbanks, Fairbanks, Alaska 99775-7320, U.S.A. \\ ${ }^{2} 222$ W 7 th Avenue 13, Anchorage, Alaska 99513, U.S.A. \\ ${ }^{3} 306$ Slone Building, University of Kentucky, Lexington, Kentucky 40506-0053, U.S.A.
}

\begin{abstract}
We employed a commercial wireline drill rig to investigate the subglacial conditions of Black Rapids Glacier, a well-studied surge-type glacier in the central Alaska Range. The four main goals were: to assess the capabilities of the commercial drilling industry for sampling subglacial material, to investigate the basal morphology, to determine the subglacial geology and to emplace borehole instruments. The drilling was done in an area where seasonal and secular variations in speed are large, and where seismic studies suggested the presence of a till layer. Four holes were drilled at three locations to a maximum depth of $620 \mathrm{~m}$. Three holes yielded samples of basal ice and till, although recovery of the latter was generally poor. Bedrock was sampled in one or possibly two of the holes. In the area sampled, the glacier is underlain by a till layer some $4-7 \mathrm{~m}$ thick, confirming the seismic interpretation. It consists of a sandy matrix at least $20-30 \%$ of which comprises larger clasts. Limited samples of the matrix indicate that near the top of the till the porosity is $40 \%$, and that some of the pore water is frozen. Geologic studies suggest that the drilling area lies to the north of the Denali Fault, a major tectonic boundary followed by the glacier, and that most of the till is locally derived with transport distances of $<2 \mathrm{~km}$.
\end{abstract}

\section{INTRODUCTION}

\section{Black Rapids Glacier}

Black Rapids Glacier is a $40 \mathrm{~km}$ long surge-type glacier in the central Alaska Range. It first came to public attention during its last surge in 1936-37, when the surge front was observed from the Black Rapids Roadhouse, situated along the Valdez-Fairbanks trail (Fig. 1). There the astounded residents radioed news of the approaching glacier to the world (Hance, 1937). An attempt to document the previous surge history has been made by Reger and others (1993).

The surge behavior and the accessibility of Black Rapids Glacier have made it an object of intensive scientific study. In 1970 the U.S. Geological Survey initiated a surveying program, measuring annual velocities and mass balance. This program was later continued by the University of Alaska Fairbanks (Heinrichs and others, 1996). Harrison and others (1975) measured near-surface temperatures and showed that Black Rapids is a temperate glacier with a cold surface layer, about $20 \mathrm{~m}$ thick, in the ablation area. Starting in 1982, cameras were placed at up to four locations along the glacier to measure the velocity of survey poles. In addition, vertical strain and passive seismicity were recorded. In 1993, a more detailed program was started, with radio-echo soundings (Gades, 1998), hydrological studies (Cochran, 1995; Raymond and others, 1995) and seismic detection of subglacial changes (Nolan and Echelmeyer, 1999a, b). In 1996 we hot-water drilled seven holes through the ice to obtain accurate ice depths and to prepare for the subglacial wireline drilling carried out in spring 1997. Water levels in these boreholes were recorded during the summers of 1996 and 1997.

\section{Geologic setting}

Black Rapids Glacier lies in the central Alaska Range, which is characterized by glacierized peaks $>4000 \mathrm{~m}$ a.s.l. The range lies along the Denali Fault, a major tectonic boundary that extends from southeast Alaska through the Alaska Range to the Bering Sea. The fault underlies Black Rapids Glacier in the vicinity of the drilling site. Plafker and others (1994) consider the fault to be active. Probable rates of dextral Holocene movement average about $15 \mathrm{~mm} \mathrm{a}^{-1}$. Estimates of Quaternary offset on the fault range from 1 to $6.5 \mathrm{~km}$, with an estimated total displacement of $300-400 \mathrm{~km}$ since Late Cretaceous (Nokleberg and others, 1994). In the vicinity of Black Rapids Glacier, the fault separates rocks belonging to the "Aurora Peak" terrane on the north from the "MacLaren" terrane to the south (Nokleberg and others, 1992). The former include Cretaceous gabbros, metagabbros, metadiorites, amphibolites and Silurian schists. The MacLaren terrane is composed of Late-Cretaceous gneissic granitic rocks, chiefly granodiorite, quartz diorite and minor granite of the "East Susitna Batholith", and of Late-Cretaceous and older schists and amphibolites. The glacier's accumulation area is situated in the "MacLaren" terrane from where it flows north and then curves to the east into a valley defined by the fault. The main part of the glacier starts flowing into the fault valley $14 \mathrm{~km}$ from its head and some $2 \mathrm{~km}$ upstream from the drill site (Fig. 1). A major tributary enters at about $23 \mathrm{~km}$, which is below the drill site.

We believe the geologic setting of the glacier is related to the surge behavior. Post (1969) recognized that surging glaciers in Alaska are not randomly distributed, and that most of the surging glaciers in the Alaska Range directly overlie the Denali Fault (his fig. 1). Wilbur (1988) did not find a one- 


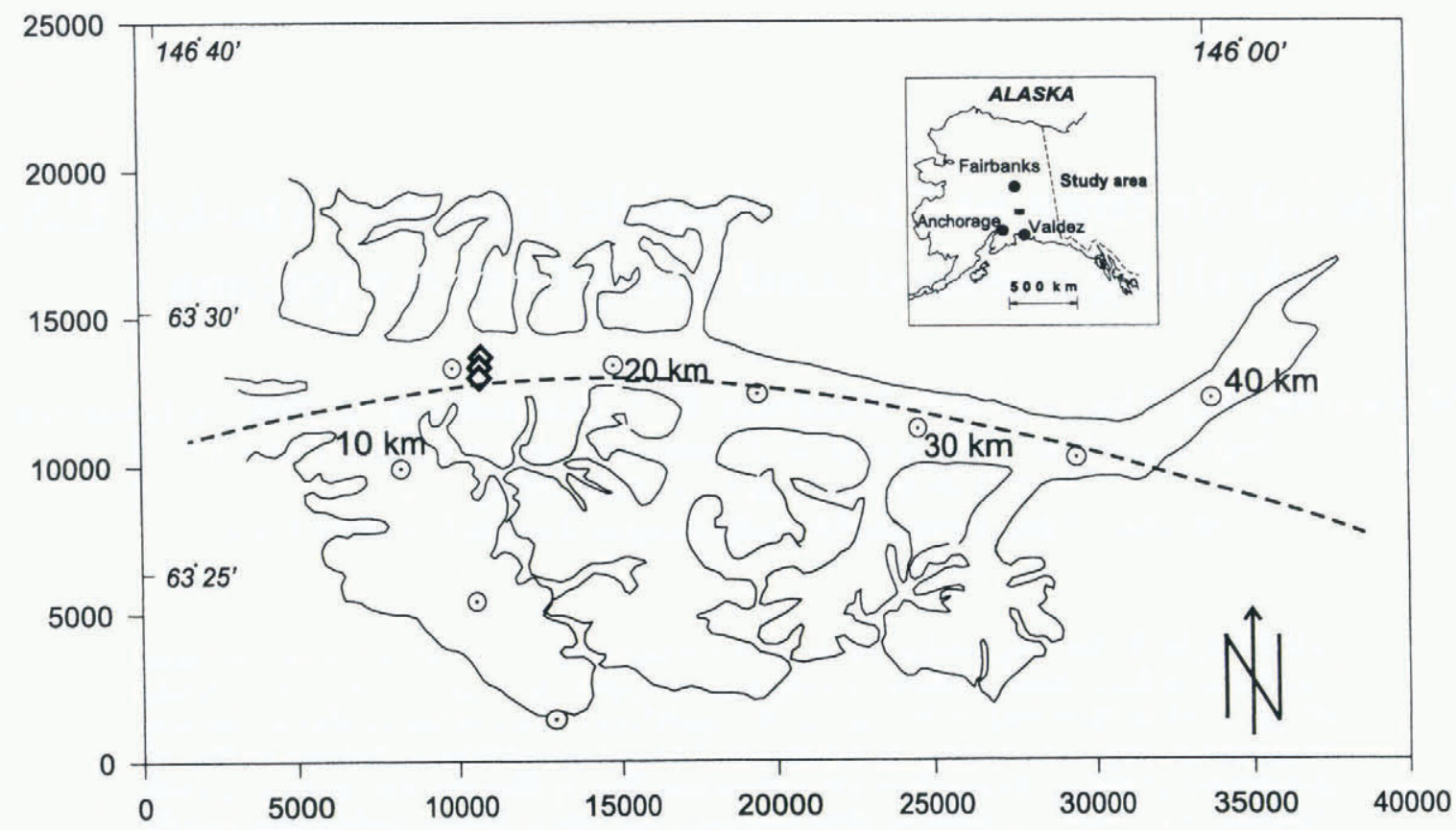

Fig. I. Outline of Black Rapids Glacier. The diamonds show, from top down, the location of holes.N2, N1 and Center. The open circles are located every $5 \mathrm{~km}$ along the center line from the head of the glacier, and a local coordinate system is shown (in meters). The approximate location of the Denali Fault is indicated by the dashed line. The glacier is situated just east of the Richardson Highway and the Trans-Alaska Pipeline.

to-one correlation between glacier geometry and surge behavior, and concluded that surge behavior was also related to regional mountain geometry and ultimately to geologic conditions. A similar conclusion was reached in a study on glaciers in Svalbard (Hamilton and Dowdeswell, 1996). Work at Findelengletscher, Switzerland, has also shown a strikingly different velocity behavior on each side of the glacier (Iken and Truffer, 1997), which may relate to differences in bedrock geology (Bearth, 1953).

\section{Drill-site location}

The drilling was done 16-17 km from the glacier head (Fig. 1). This is the area where the seasonal and longer-term variations in speed are largest, and basal motion is thought to be large (Heinrichs and others, 1996). It is about $4-5 \mathrm{~km}$ downstream of the present-day equilibrium line, and lies down-glacier from marginal and supraglacial lakes (potholes) that frequently drain in early summer (Sturm and Cosgrove, 1990) and cause speed-up events. The glacier undergoes a spring speed-up, typically in early June. Nolan and Echelmeyer (1999a, b) inferred from a seismic study the existence of a subglacial till layer at least $5 \mathrm{~m}$ thick. This layer became seismically transparent during speed-up events. The subglacial seismic changes were observed at the N1 site (Fig. 2), where two of the boreholes were drilled. Figure 3 shows a longitudinal radio-echo sounding profile (Gades, 1998 and unpublished data). The boreholes were drilled in a subglacial hollow, directly upstream of a riegel. The ice thickness is decreasing and the glacier is slowing down between $14 \mathrm{~km}$ and $20 \mathrm{~km}$ (Heinrichs and others, 1996).

It should be kept in mind that all the results presented here describe only a small part of the glacier.

\section{Sampling of subglacial till}

Basal glacial processes are important for understanding glacier dynamics. This has led several investigators to take a

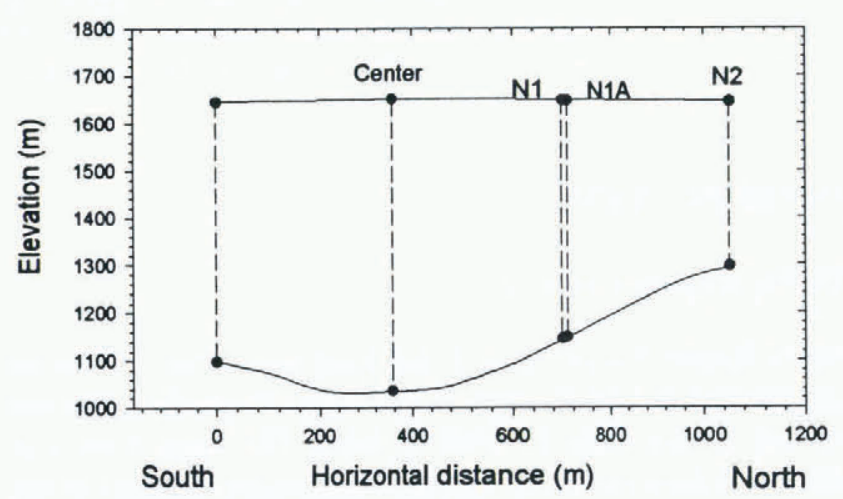

Fig. 2. Transverse profile with borehole locations. The southernmost hole is a hot-water hole where no subglacial samples were taken. The ordinate axis shows elevation above sea level.

closer look at subglacial sediments, sampling them and making in situ measurements. In this paper we refer to any unlithified subglacial material as till (Paterson, 1994). Early observations of subglacial till were made at Blue Glacier by Harrison and Kamb (1973) and Engelhardt and others (1978). Samples of fine-grained till with a small clast content have successfully been retrieved from beneath Ice Stream B, West Antarctica, with a piston corer (Engelhardt and others, 1990; Kamb, 1991). Boulton and Hindmarsh (1987) studied the till beneath Breidamerkurjökull, Iceland, through a tunnel at the glacier terminus. Extensive borehole studies of in situ subglacial till properties have been undertaken on Trapridge Glacier, Yukon Territory, Canada (e.g. Blake and others 1992, 1994; Fischer and Clarke, 1994), Storglaciären, Sweden (e.g. Iverson and others, 1994; Hooke and others, 1997), and Columbia Glacier, Alaska (Humphrey and others, 1993).

With simple borehole instruments, it is only possible to penetrate subglacial till to a depth of about $40 \mathrm{~cm}$ or less. It is often difficult to assess the exact depth of an instrument in relation to the ice-till interface (assuming a sharp interface 


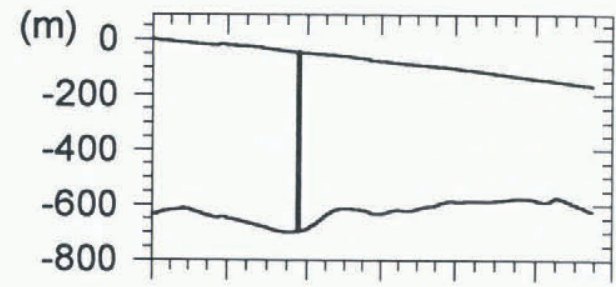

$\begin{array}{lllllll}14 & 15 & 16 & 17 & 18 & 19 & 20\end{array}$

\section{Centerline coordinate $(\mathrm{km})$}

Fig. 3. Longitudinal profile of ice surface and glacier bed from the $14 \mathrm{~km}$ to the $20 \mathrm{~km}$ index site (Fig. 1). The vertical line shows the location of the boreholes. Data are from Gades (1998 and unpublished).

exists), because the hot-water drill stirs up the till and can drill through fine-grained tills. On the other hand, debrisrich ice can stop the hot-water drill above the glacier bed.

Subglacial till is extremely difficult to sample. Unlike the marine sediments underlying the West Antarctic ice streams, most glacial till contains numerous clasts of many sizes. Such clasts will invariably stop or jam piston corers. Sampling attempts have thus often met with little success. A split-spoon sampler was used on Storglaciären, yielding disturbed samples (personal communication from N. R. Iverson, 1998). Blake and Clarke (1991) described how a sediment sampler that works by sucking sand and pebbles up into the sampler was used on Trapridge Glacier. This sampler is sizeselective, however, and does not yield representative samples (personal communication from G. K. C. Clarke, 1998).

The idea behind our project was to exploit existing drilling technology in an attempt to retrieve complete core samples of basal ice, subglacial till and the underlying bedrock. This would allow us to study the basal morphology and the bedrock geology. At the same time, we hoped to use some of the boreholes to install instruments for in situ measurements of borehole tilt and pore-water pressure. We believe that obtaining undisturbed samples of subglacial till, although very difficult to do, is of primary importance. Although there is a large research effort in modeling till deformation, there are only a limited number of in situ measurements and actual samples.

This paper describes the drilling technology used and an analysis of the recovered samples. The results from the borehole instruments will be published separately.

\section{METHODS}

\section{Drilling}

Drilling into the basal ice, till and bedrock, and the sampling, were done with a commercially contracted wireline drill system. The size of the drill rig was determined by the diameter of the core sample needed and the portability of the drill rig. A Longyear Super 38 (Fig. 4) was selected, allowing us to drill to at least $650 \mathrm{~m}$ and obtain a $60 \mathrm{~mm}$ diameter core. This drill is helicopter portable, breaking down into five pieces, the largest weighing approximately $450 \mathrm{~kg}$. A drill rod of HQ size $(78 \mathrm{~mm}$ inner diameter) was used in the shallower holes, and one of NQ size $(60 \mathrm{~mm}$ inner diameter) in the deepest hole. This was done for safety reasons because an HQ string of $>600 \mathrm{~m}$ was deemed too heavy for the drill rig: $6866 \mathrm{~kg}$ for HQ vs $4544 \mathrm{~kg}$ for NQ. In some

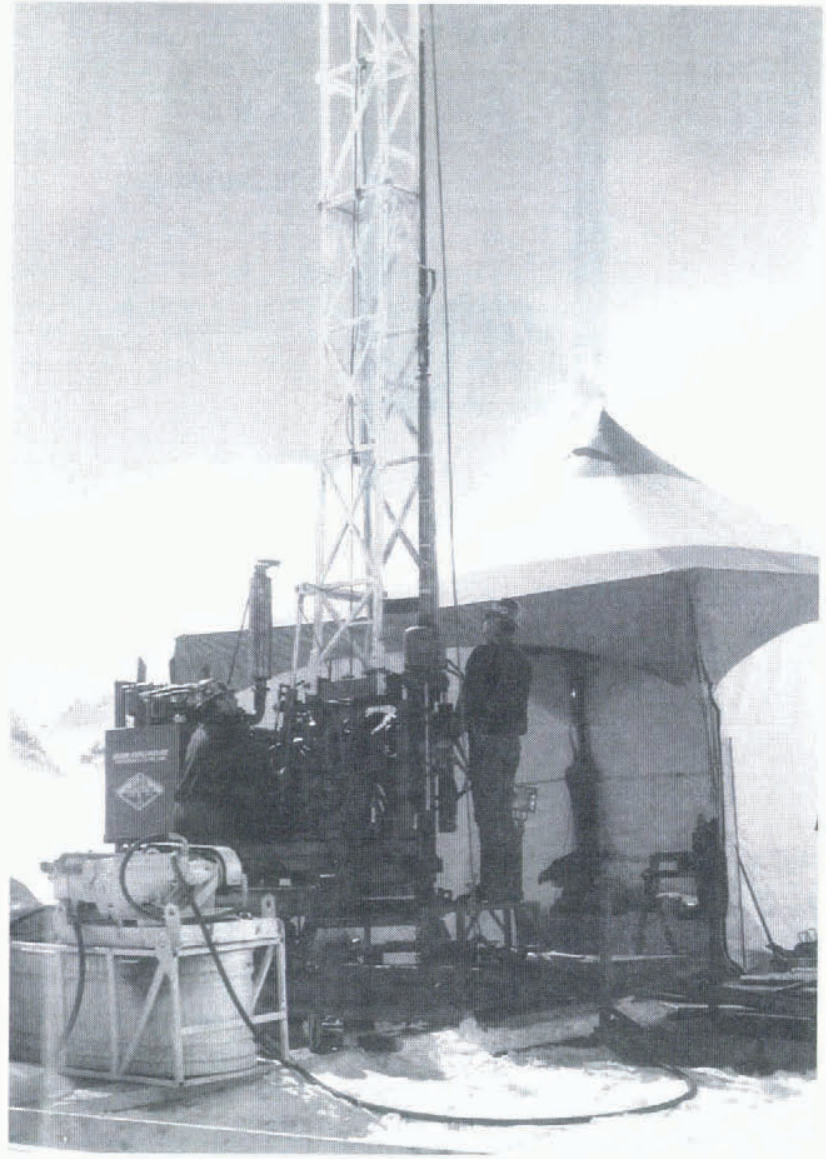

Fig. 4. Photograph of the drill rig. As drilling proceeds, $10 \mathrm{ft}$ $(3.05 \mathrm{~m})$ sections of drill rod are lifted up on the tower and then connected to the drill string.

cases, the narrower drill rod can be used inside the larger, with the larger as casing for the hole. Sections of drill rod, each $10 \mathrm{ft}(3.05 \mathrm{~m})$ long, were added as drilling proceeded.

The bottom section of the drill string is called a core barrel (Fig. 5). It carries a shoe with the drill bit at its end. It contains an inner tube that can be pulled out through the entire rod by a wire cable; hence the name wireline drilling. The inner tube is equipped with a core retainer. This can be either a spring retainer that works through wedging action, or a plastic basket, depending on the expected sample material. A sample of $10 \mathrm{ft}(3.05 \mathrm{~m})$ or less can thus be pulled out without taking the entire drill string out of the hole. The drill rod effectively cases the hole during sampling. The core barrel is equipped with a latching mechanism for the inner tube. Failure of this latching mechanism was a chronic problem that we were unable to diagnose. Sometimes the problem could be fixed by raising the entire drill string a few meters and rotating it rapidly. This is not an ideal solution, since it allows the lowest part of the borehole to cave in and necessitates some redrilling.

Two drill bits were used: a carbide bit to drill through ice and soft till, and an impregnated diamond-core bit to drill through till and bedrock. The carbide bit wears out quickly when used in hard rock, and drilling through ice with the diamond bit was as slow as $0.5 \mathrm{~m} \mathrm{~h}^{-1}$, compared to $2-5 \mathrm{~m} \mathrm{~h}^{-1}$ with the carbide bit. A surface-set diamond-core bit might be a better choice for drilling in ice. Typical drilling speeds were about $2 \mathrm{~m} \mathrm{~h}^{-1}$ in till and $\sim 1-1.5 \mathrm{~m} \mathrm{~h}^{-1}$ in bedrock. Pulling out the core barrel through $600 \mathrm{~m}$ of drill string takes about $30 \mathrm{~min}$, provided everything goes well.

Ideally, softer material is sampled with a punch corer. 


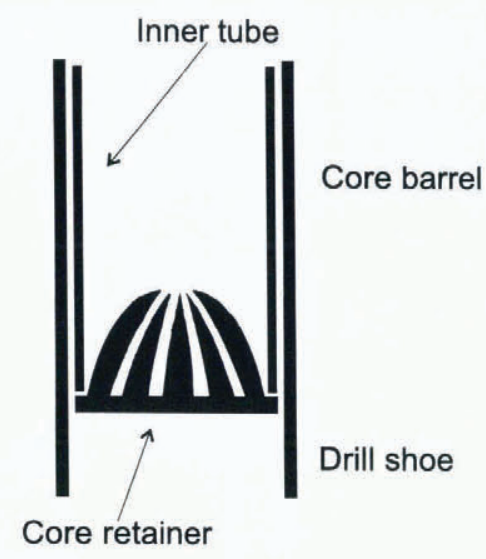

Fig. 5. Schematic drawing of the core barrel, the lowermost section of the drill string. The drill bit is attached to the core barrel's bottom. The inner tube is retrievable through the drill string. It carries a core retainer at the bottom. A plastic basket core retainer that was used to sample till material is shown.

Some core barrel designs combine a retractable punch corer with a drill bit. This allows the punch corer to be pushed ahead through softer sediments, with the bit engaging any harder material. We did not use this set-up, however, because the subglacial till contained cobbles the size of the diameter of the punch corer, and these could easily damage or plug the corer and, hence, require pulling the entire drill string.

Because we were interested only in basal material, we pre-drilled holes into the ice using a conventional hot-water drill (e.g. Iken and others, 1989), which is much faster and cheaper. The water was recovered from the borehole for reuse using a submersible pump. The rotary drill also required recovered water for cooling and flushing the drill bit. Ice depths were known from seismic and radar measurements and hot-water drilling done the previous year. In some holes we stopped the hot-water drill a few meters short of the bed, so that basal ice could be sampled as well. The actual ice-till interface was within $2 \mathrm{~m}$ of what we expected from hotwater drilling at N1 and Center. At N2 we expected to reach the bed at $341 \mathrm{~m}$, but we had not reached it when we abandoned the hole at $348 \mathrm{~m}$.

During normal operation the drill rod cases the hole and prevents till from collapsing and closing the hole. If the drill string has to be pulled out, a special polymer ("drill mud") is pumped into the hole before pulling. This helps prevent the hole from collapsing for a short period of time. For reasons not entirely clear to us, a lower concentration of the polymer was also used during normal drilling operation. If the hole stays open after removal of the drill string, borehole instruments may be emplaced once the drill string is removed. Ideally, instruments could be introduced through the drill string, which would then be pulled out over the instrument cable. Unfortunately our instruments were too large to fit through the drill bit, but we were able to install a string of three tiltmeters and one piezometer at the base of one of the boreholes.

\section{Logistics}

A drilling operation of this kind adds a whole new dimension to fieldwork on valley glaciers. Including camp and fuel, a total of $>40000 \mathrm{~kg}$ of material was flown to the glacier, by a combination of helicopter and fixed-wing aircraft. The fixed-wing aircraft was much less expensive, but loading and unloading was more efficient with a helicopter, which was also needed to assemble the drill rig on the glacier.

When assembled the drill rig was mounted on a large steel toboggan to distribute its weight. It could be moved on the glacier using large snow anchors ("dead men") dug into the snow. The rig was then pulled using its own wireline winch system.

Our drilling was performed in late April and early May, before any significant melting occurred, thus avoiding most problems with transport on a wet snow surface. Also, we expected the drilling to be easier before any accelerated basal motion occurred.

Due to the relatively high stand-by cost of this drill rig, it proved advantageous to work in two 12 hour shifts. Special arrangements were needed to keep the crew out of the wind and the low temperatures, which at that time of year can reach $-30^{\circ} \mathrm{C}$. Directly adjacent to the drill rig a large heated tent was set up, allowing most of the work to be done in somewhat less harsh conditions (Fig. 4).

\section{THE DRILL HOLES}

Four holes were drilled at three sites on a transverse section: N2, N1 and Center (Fig. 2). At N2, wireline drilling commenced at $336 \mathrm{~m}$ depth and continued through $12 \mathrm{~m}$ of ice (Fig. 6) before the hole was abandoned because of problems with moving the core barrel up and down the string. Subsequent inclinometry showed that the hot-water drilled hole was $>4^{\circ}$ out of plumb at some places. We suspect that this was due to debris-rich ice or to rocks on the surface that fell into the hole. The proximity of a medial moraine and the slow hot-water drilling rate lend support to this inference.

Wireline core drilling at N1 commenced at $488.5 \mathrm{~m}$ depth and eventually reached $510.1 \mathrm{~m}$ (Fig. 7). Hole $\mathrm{N} 1$ provides the most complete picture of the ice-till-bedrock structure of the four holes. Drilling through the till presented major challenges. Equipment failure and other problems required pulling of the entire drill string three times before $\mathrm{Nl}$ was completed, a tedious and labour-intensive undertaking. Each time the drill string was removed, till collapsed into the uncased hole, requiring redrilling. We therefore cased the hole with the wider $\mathrm{HQ}$ rod and drilled inside it with the NQ rod. In this manner we eventually reached bedrock or a large boulder. The hole had to be abandoned when the lowest $6 \mathrm{~m}$ of the string was twisted off, possibly because of borehole deformation and/or basal motion.

A second hole at this site, N1A, was drilled to obtain till samples and to place a string of three tiltmeters and one piezometer into the till layer. To accelerate the drilling process and avoid time-consuming wireline coring through ice, hot-water drilling was used to penetrate all the way to the ice-till interface, located at $\sim 498.5 \mathrm{~m}$ (Fig. 8). Thus no ice samples were obtained, but till was successfully recovered in the first $3 \mathrm{~m}$ section of core below the interface. Instruments were installed successfully in the till after the drill string was pulled.

The Cienter hole was the deepest (about 610 m; Fig. 9). The NQ rod was used to reduce the weight of the drill string. Wireline coring of ice began at $602.0 \mathrm{~m}$, but was abandoned in favor of hot-water drilling at $607.5 \mathrm{~m}$. The hot-water drill was lowered inside the drill rod to avoid pulling of the entire drill string. Coring recommenced at $614.8 \mathrm{~m}$ and continued to $621.2 \mathrm{~m}$ after penetrating bedrock at $619.5 \mathrm{~m}$. 


\section{Hole N2}

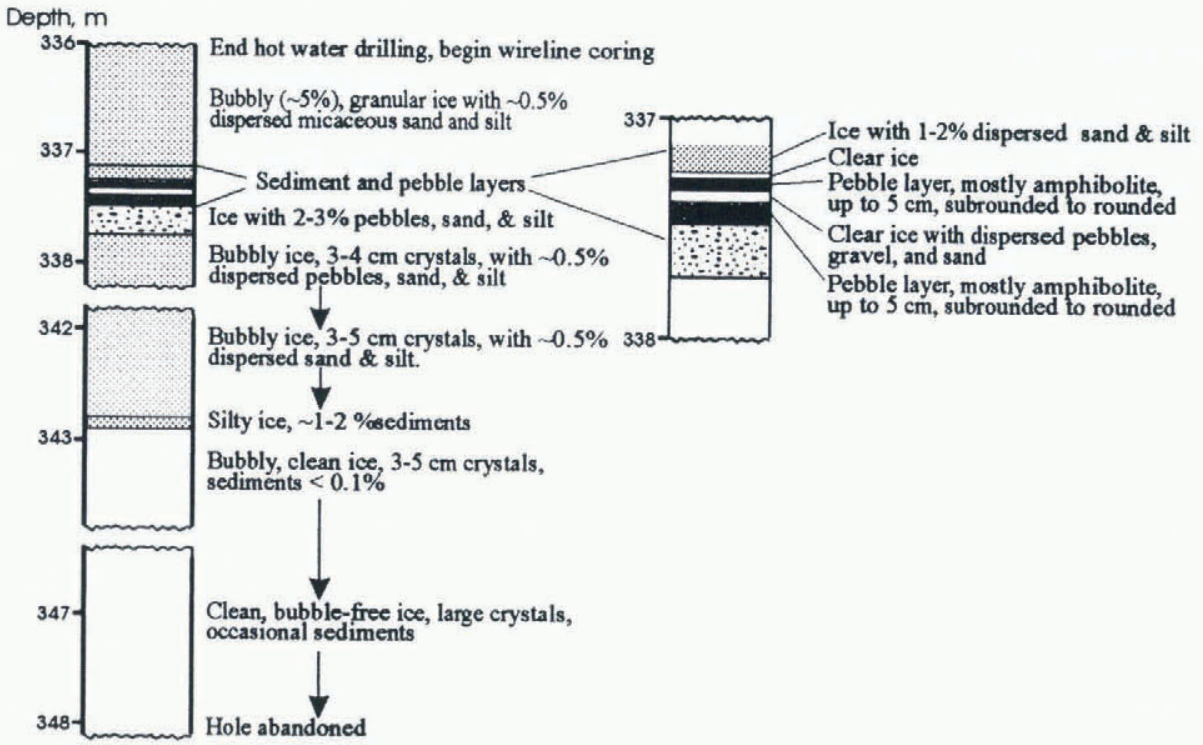

Fig. 6. Section of the $\mathcal{N} 2$ samples. A combination of radio-echo sounding and seismic measurements yielded a depth of $360 \mathrm{~m}$.

\section{RESULTS}

\section{Basal ice}

Ice samples were obtained from near the bottom of three of four holes drilled. However, only at $\mathrm{Nl}$ was ice retrieved from the ice till interface. The coring process commonly fractured the ice into short, cm-scale, disks.

At N2, wireline drilling stopped several meters above the bottom. At $337-338 \mathrm{~m}$, coring intersected two distinctive, several $\mathrm{cm}$ thick layers of subrounded to rounded pebbles, primarily black amphibolite (Fig. 6). The pebble layers contained no ice when recovered, and lacked finer-grained sediment, but were separated by a thin layer of clear ice containing dispersed finer sediments. They were bracketed by ice containing entrained pebbles and finer sediments. The ice generally decreased in bubble content and entrained sediments with depth below the layers, and crystal sizes were $3-5 \mathrm{~cm}$.

The first section of core at N1 was only partially recovered but contained distinctive layers of frozen sediment and a layer of pebbles (see Fig. 7). Sediments finer than coarse sand were absent. Pebbles were more angular than those at $\mathrm{N} 2$ and included dioritic gneiss as well as amphibolite. A thin ice layer separated two of the sediment layers. No other ice was recovered in this section of the core. It is possible that the sediments and structure are artifacts of the hotwater drilling that preceded the wireline coring, as it causes most of the sediments it drilled to accumulate at the bottom of the hole. Below this section, we recovered a nearly continuous core of ice from $\sim 491.5 \mathrm{~m}$ to the till interface at $\sim 502 \mathrm{~m}$ (Fig. 7), consisting mostly of clear, relatively bubble-free ice, with occasional thin silt layers. A $30^{\circ}$ dipping sand layer was encountered at $496.5 \mathrm{~m}$. Between 497.5 and $501 \mathrm{~m}$, two close-set, sub-parallel, steeply dipping silt-mud layers of variable thickness (averaging $3 \mathrm{~cm}$ ) were encountered. They have the appearance of mud--silt dikes filling ice fractures. Several thin, mm-scale, mud-silt layers occur just above the till interface. Analysis showed that $>60 \%$ of these layers consist of grains smaller than $44 \mu \mathrm{m}$ : silts and clays. Details of structure immediately at the interface were not preserved, and some sediments and ice were lost in the drilling process.

About $7.5 \mathrm{~m}$ of ice was recovered from the Center hole. A $6 \mathrm{~cm}$ layer of frozen, poorly sorted sediments was found near the top of the retrieved sample, a layer which may have stopped the initial hot-water drill from progressing (Fig. 9). The rest of the core consists of clear ice with occasional bubbles, clumps of clay and thin silt layers.

\section{Subglacial till}

Till was reached in three of the four holes. Recovery of till was extremely difficult, for two reasons. The first was the use of pumped water to cool and flush the drill bit in order to prevent the bit from melting, as happened on one occasion. The stream of water caused the fine sediments, sand and even gravel to be washed away from the core barrel, preventing sampling. The other problem involved the clogging of the entrance of the core barrel with clasts and fragments of rocks which then prevented entry of any further material. When using the spring retainer most of the material slipped out, while the basket retainers (Fig. 5) tended to become clogged. The problem of washing-out can be reduced by using a minimal amount of water to cool the drill bit, and perhaps by using a combination of punch-coring and rotary drilling, but this was not done for the reasons explained earlier.

Despite these obstacles, retrieval of small samples of till matrix was achieved on two occasions through judicious drilling. In addition, a variety of rock fragments was recovered, giving some indication of the nature and size of clasts contained in the till. The clast-shape classification used below is subjective. We divided shapes into four categories: rounded, subrounded, subangular and angular.

\section{N1 hole}

The first sample of intact till matrix was recovered in hole N1. Prior to sampling, the drill string was removed from the hole, and then reinserted about $60 \mathrm{~h}$ later. Either material had fallen in from the sides, and we recored it, or we lost the lower part of the hole and drilled a new one. This is apparently not uncommon. While recoring, we sampled a sec- 


\section{Hole N1}

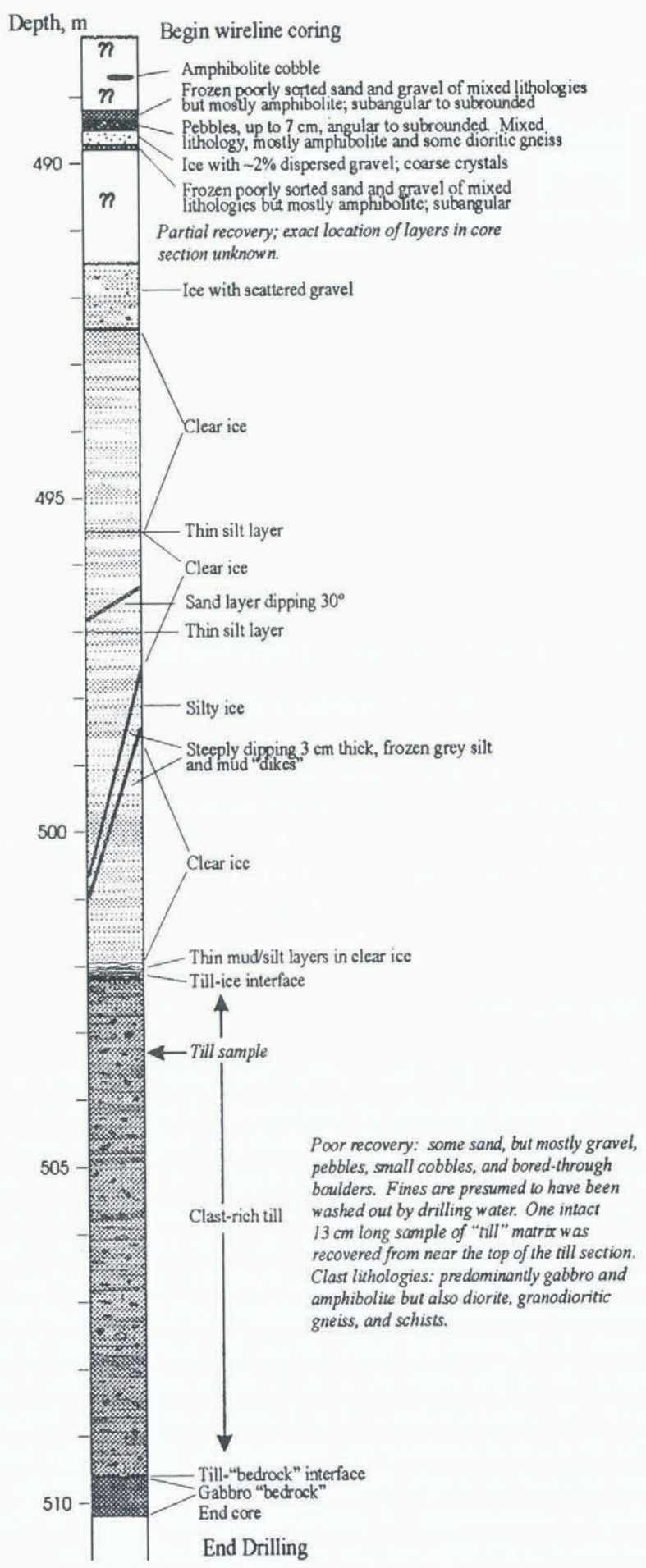

Fig. 7. Section of the N1 samples. A combination of radio-echo sounding and seismic measurements yielded a depth of $500 \mathrm{~m}$.

tion of till about $100 \mathrm{~mL}$ in volume. It was located within the first $1.0 \mathrm{~m}$ below the ice-till interface. The fragment was mechanically coherent when it came out, but it decayed into a slurry after exposure to above-melting temperatures for $<2$ hours. The water content of the sample, defined as the ratio of the weight of water to that of dry soil (Lambe and Whitman, 1979), was $21 \%$. The results of a grain-size analysis are shown in Figure 10a; the sample contained mostly sand and had a grain-size distribution similar to that of other basal tills (e.g. Jiao Keqin and others, 1989). Only 6\% of the sample is silt and clay, as compared to $30-40 \%$ clays in Ice Stream B samples (Tulaczyk and others, in press). Grain- sizes greater than $2 \mathrm{~mm}$ were mostly lithic fragments. The larger grain-sizes were subangular to subrounded, with some degree of roundness observed in grain-sizes as small as $1 \mathrm{~mm}$. Sediment below this size was much more angular and predominantly composed of individual mineral grains.

An undisturbed cylindrical sample, $11 \mathrm{~cm}$ by $5 \mathrm{~cm}$, was recovered in hole N1A. It was located at the top of the first core below the ice-till interface. Only $1.2 \mathrm{~m}$ out of $2.4 \mathrm{~m}$ were sampled, leaving an uncertainty of $1.2 \mathrm{~m}$ for the exact location of the sample. The sample was mechanically coherent when it came out, and we stored it at sub-freezing temperatures. Its water content was $29 \%$, and the porosity was $40 \%$. When the sample was thawed, it turned into a slurry, much like the N1 sample described above. Laboratory measurements showed that the water content at the Atterberg liquid limit was $10 \%$, less than half the observed water content. A soil at this liquid limit has a strength of about $20 \mathrm{kPa}$ (Bowles, 1992). Only $4.4 \%$ of the sample was in the silt and clay fraction (Fig. 10b).

Other, smaller, pieces of till were closely monitored when retrieved. They could easily be broken apart. There were some ice crystals on the samples' surfaces. We believe that we saw interstitial liquid water, however, when breaking them apart. The ice could have formed because of the pressure release or because of the generally low air temperatures.

We do not think that it would have been possible to retrieve these samples if all the water had been in liquid form. We therefore conclude that some of the water was in the form of ice, albeit microscopic in size as ice crystals were not observed inside the specimens, even with a hand lens. The fact that the samples could easily be broken apart suggests that they were not frozen solid in situ. During drilling through debris layers in basal ice at $\mathrm{N} 2$ and Nl, the ice was not melted by the drilling. Judging from that experience we do not think that the drilling could have melted a substantial fraction of interstitial ice. Also, if ice had been melted by the drilling, we would expect a melted outer layer and a frozen inner core. This was not observed.

Roughly 165 clasts greater than $1 \mathrm{~cm}$ were recovered from till in holes $\mathrm{Nl}$ and $\mathrm{N} 1 \mathrm{~A}$, including cores and fragments of several $7-13 \mathrm{~cm}$ thick cobbles and boulders. The clasts consisted of $42 \%$ (by number) gabbro similar to underlying "bedrock" (see below), 25\% amphibolite, 14\% gneissic granite, $14 \%$ light-colored micaceous schist and $5 \%$ dioritic rocks similar to bedrock at Center (see below). Most of the clasts were oblong, and subangular to subrounded, although angular and rounded clasts were also found.

Because of poor recovery, the volume concentration of clasts greater than pebble size is difficult to determine. A minimum can be estimated from the first sample extracted from N1A. The thickness of till recovered is about half the $2.4 \mathrm{~m}$ drilled. If we assume the missing fraction is due to washing away of gravel-size and smaller sediments between the intact till pieces, then rocks pebble size or larger would comprise at least $20-30 \%$ of the till at N1A. Assuming bedrock was reached, we drilled through $7.5 \mathrm{~m}$ of till at $\mathrm{Nl}$.

\section{Center hole}

Till from the top of the Center hole appears to have been reworked by hot-water drilling judging from the moderate sorting the sediments displayed upon recovery. Far fewer clasts $(\sim 25)$ were recovered than at $\mathrm{Nl}$ and N1A, perhaps because of the narrower diameter of the drill core. Alternatively, till at Center may not be as clast-rich as at $\mathrm{Nl}$ and 


\section{Hole N1A}

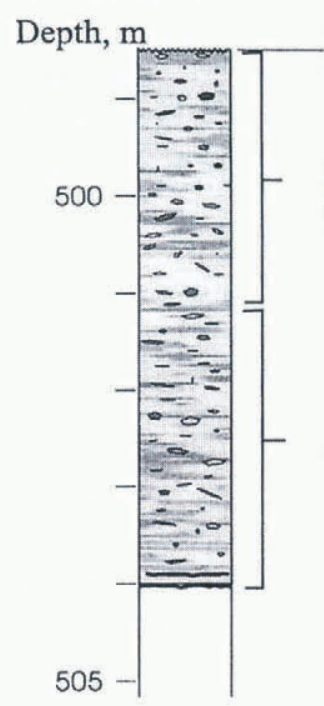

End hot water drilling;

begin wireline coring

"Till"

$50 \%$ core recovery. Alternating till

matrix and rubble layers. Some

sediments partially or totally washed out. See detail.

"Till"

Very poor recovery. Core catcher

jammed with rock fragment preventing

collection of samples.

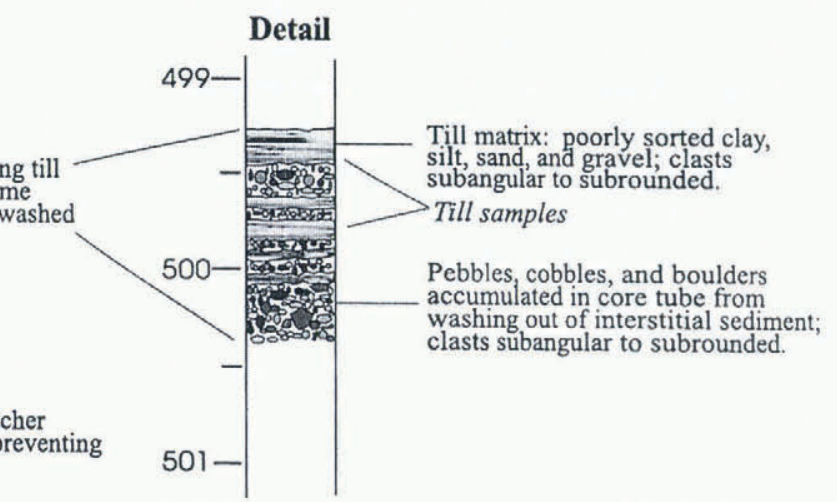

End drilling, hole abandoned

Fig. 8. Section of the N1A samples.

\section{Hole "Center" (NQ rod)}

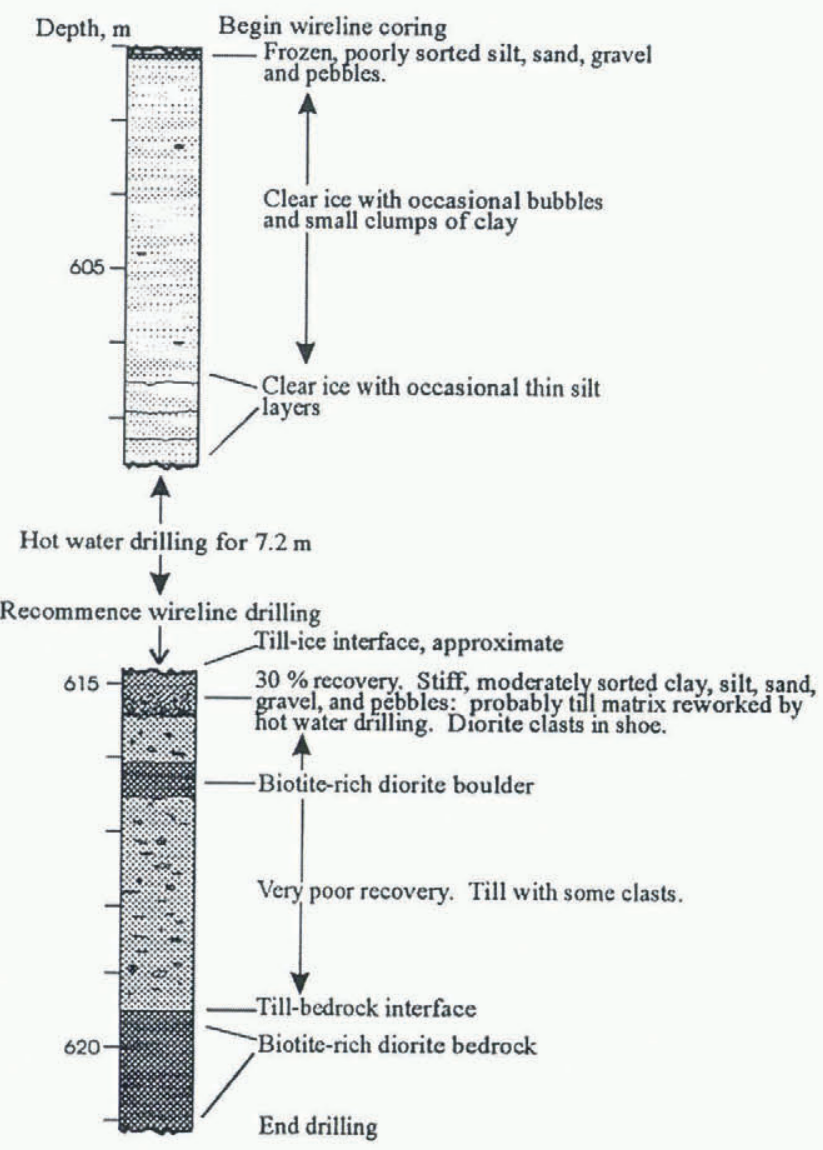

Fig. 9. Section of the Center samples. A combination of radioecho sounding and seismic measurements yielded a depth of $620 \mathrm{~m}$.

NlA. A large, $50 \mathrm{~cm}$ thick, boulder of diorite composition was drilled through. The remaining clasts were predominantly biotite-rich diorite, similar to underlying bedrock, plus quartz pebbles, micaceous schist and granodiorite. The till layer at the Center hole was $4.5 \mathrm{~m}$ thick, $3 \mathrm{~m}$ thinner than at $\mathrm{Nl}$. particle size $(\mathrm{mm})$

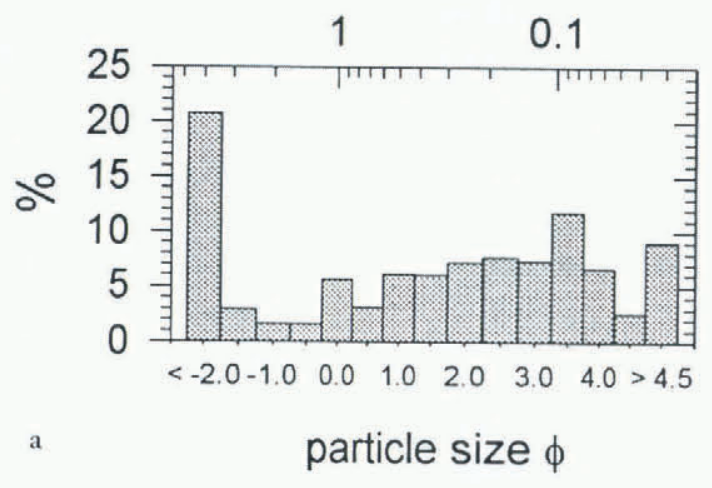

\section{particle size $(\mathrm{mm})$}

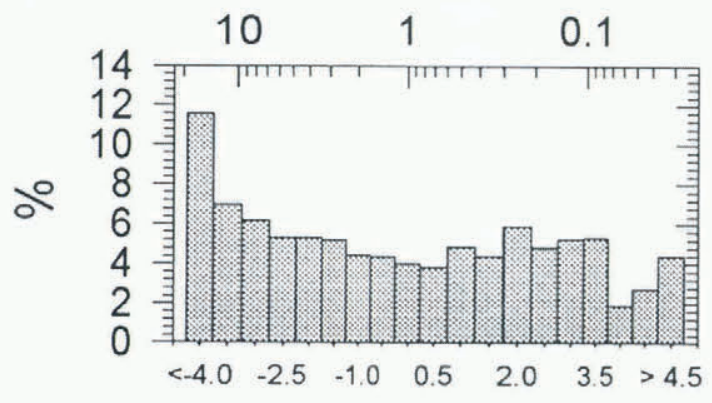

b

\section{particle size $\phi$}

Fig. 10. Grain-size distributions of two pieces of till matrix recovered from ( $a$ ) the N1 borehole and ( $b$ ) the N1Aborehole.

\section{Bedrock}

We recovered rock cores from the bottom of two of the drill sites, $\mathrm{Nl}$ and Center (Fig. 2). The rock core retrieved from N1 was $0.6 \mathrm{~m}$ long. Geochemistry and mineralogy identify the rock as a two-pyroxene, metal-sulfide-bearing gabbro. The lithology of the basal rocks most closely resembles the "gabbro of Mount Moffit" which outcrops at the base of Mount Moffit to the north of the drill site (Nokleberg and 
others, 1992). Although fractured and fragmented by drilling, the core appears to be continuous. However, it displayed significant dissimilarities in pyroxene characteristics between top and bottom, suggesting it may not be continuous bedrock, but instead boulders overlying bedrock of similar lithology. Alternately, the dissimilarities may indicate small-scale layering in the intrusion.

Fractured but continuous rock core, $1.5 \mathrm{~m}$ long, was recovered from the bottom of the Center hole (Fig. 9). Grinding between the different pieces of bedrock had occurred during the drilling. Geochemistry and mineralogy of rock samples taken from the top, bottom and middle of the core are essentially identical: a two-pyroxene, metal-sulfidebearing, biotite-rich diorite with minor quartz and potassium feldspar but no hornblende. The identical chemistry and length of core imply that the entire sample is bedrock, although it could also be a single very large boulder. Thus, although Center and $\mathrm{Nl}$ are only $300 \mathrm{~m}$ apart, the lithologies of "bedrock" samples from the two drill sites appear to be distinctly different. The closest possible nearby relative to Center bedrock is metadiorite of somewhat similar composition that is exposed $6-10 \mathrm{~km}$ west of the field site in the Aurora terrane on the north side of the fault (Nokleberg and others, 1992). However, Center bedrock is distinctly plutonic, not metamorphic. No diorite occurs to the south or upstream of the drill sites. The closest possible relatives in MacLaren terrane rocks are the gneissic granodiorite of the "East Susitna Batholith", south of the glacier (Nokleberg and others, 1992). Thus, not only do the "bedrock" lithologies differ, they also appear distinctly different from mapped outcrops upstream of the sites. Given the dextral offset along the Denali Fault, the bedrock encountered in the drill holes could be slivers that have been displaced long distances from their point of origin, and may have no relationship to rocks surrounding the glacier. Megascale faults such as the Denali usually have broad shear zones, up to $1 \mathrm{~km}$ or more in width, and our drill sites may well lie over such a shear zone. Alternatively, the gabbroic batholith exposed at the base of Mount Moffit to the northeast of the drill site may extend under the glacier and could be the same gabbro encountered at N1. The latter hypothesis could be tested with further analysis of each gabbro and Ar-dating.

\section{DISGUSSION}

The results presented above prompt the following questions:

(i) How much ice is contained in the till?

(ii) Is the till-water-ice mixture stable?

(iii) How was this ice formed?

(iv) What can we infer about erosional and depositional processes?

(v) What is the origin of the debris layers in the basal ice?

(vi) What are the implications for the surge behavior?

\section{Ice content of the till samples}

In the previous section we argued that some of the till samples recovered in the uppermost meter of the till layer at the $\mathrm{Nl}$ and N1A boreholes contained ice. The samples were not frozen solid, since they could easily be broken apart. If the ice was simply part of the solid soil structure, about half of the water $(10-15 \%$ of the total sample's weight) would have to be in solid form in order to keep the water content below the liquid limit. We think this is an upper limit, because ice also has a bonding effect that can increase the stability of the whole matrix. We cannot give a lower limit. Also, it is not clear how the ice is distributed in the till. This is an important question and relates to the stability of the till-water-ice mixture.

\section{Stability of an ice-water-till conglomerate}

When either one of the till samples was dried and reconstituted with a water content of $>11 \%$, it essentially turned into a slurry. This means that the sample is supersaturated at zero effective pressure (difference between overburden and porewater pressure). That leaves us with two possibilities:

(a) The till consists of a fragile skeleton of high porosity (higher than a sample consolidated in the laboratory) that is stabilized by the bonding action of the ice. There would be grain-to-grain contact and the soil skeleton would fully carry the overburden pressure.

(b) Some of the ice helps bear the overburden pressure. If the interstitial water is connected to a subglacial hydraulic system it would presumably be at a lower pressure and therefore have a higher melting point. Heat flow from the water to the ice would be established and the ice would melt.

Therefore, we sampled till that was potentially unstable in the configuration we encountered. This instability could be temporal - ice in till was formed at some earlier time in a different flow regime and is now melting - or spatial, where ice is being formed upstream and melting out at the drilling site. If such a hypothetical instability is more than a local effect, it could relate to observed velocity variations on different time-scales (Heinrichs and others, 1996).

\section{Formation of ice in the till}

Two processes allow the formation of ice in till: regelation and freeze-on of water and till particles onto the basal ice. Regelation of basal ice into a till layer was described by Iverson and Semmens (1995) who also explored this idea experimentally. They concluded that under conditions similar to those at Black Rapids, one would not expect regelation to proceed much further than $1 \mathrm{~m}$ into the till layer. At this depth, the downward migration of the ice front would be roughly balanced by melting due to the geothermal heat flux and strain heating, but we did not sample any till matrix below $1.2 \mathrm{~m}$ from the ice till interface. Thus regelation can possibly explain ice in the till.

A more detailed treatment of regelation of ice into a till layer shows that a regelation front would be uneven because ice would not regelate through small passages due to surface tension effects. This was treated by Everett (1961) and applied to subglacial tills by Tulaczyk (in press). The driving force for regelation is the effective pressure (difference between iceoverburden and pore-water pressure). A simple calculation shows that effective pressures of $100 \mathrm{kPa}$, typically observed beneath Black Rapids Glacier, would not drive regelation through pore spaces smaller than $\sim 10^{-6} \mathrm{~m}$. Borehole measurements show effective pressures that are one order of magnitude higher during short periods in summer. During such 
times regelation could proceed through passages larger than $\sim 10^{-7} \mathrm{~m}$. The recovered till seems too coarse, however (Fig. 10 ), for this mechanism to be used to explain the high water contents. A knowledge of the size of pore spaces and passageways would be required to settle this question.

Ice in a water-saturated till matrix can also be formed because of cold patches, where the local temperature is below the pressure-melting point. In general, there are more heat sources than heat sinks beneath a glacier (geothermal heat, strain heating). Drake and Shreve (1973) proposed a heat-pump effect: water that is melted in highpressure areas flows away and does not refreeze at the immediately adjacent low-pressure area. This leaves cold patches that advect down-glacier. Robin (1976) estimated that a temperature anomaly of as much as $0.5^{\circ} \mathrm{C}$ below the local melting point could extend about $2 \mathrm{~m}$ into the basal ice. Such a cold layer would only be enough of a heat sink to freeze a few $\mathrm{cm}$ of interstitial water at the top of the till layer, which is too little to account for the sample recovered from near the top of the layer.

Nolan and Echelmeyer (1999b) proposed large variations in the local overburden pressure due to hydraulic jacking. This would happen at times of high water discharges, such as lake drainages, when the subglacial channels are overpressured. Reduction of the overburden pressure would raise the melting point and some water would freeze. One should expect this ice to melt again as the ice relaxes and the overburden is effective once again.

Röthlisberger (1968) suggested that water derived from an area where the glacier is thicker (and the melting point lower) could flow downstream and freeze there, because it would be below the local melting point. The drilling site is just downstream of a maximum in ice thickness. Between the location of maximum thickness and the drilling site there is a decrease in ice thickness of $11 \mathrm{~m}$ and a drop in bedrock elevation of $3 \mathrm{~m}$ (A. M. Gades, unpublished data). The $11 \mathrm{~m}$ change in thickness causes a change in the pressuremelting point of about $0.0073 \mathrm{~K}$. This is slightly more than the warming of the meltwater that would be expected due to the loss of gravitational energy. However, these numbers are all well within the margin of error of the radio-echo sounding - about $10 \mathrm{~m}$ - and we cannot make any definite conclusions in this regard.

In summary, regelation and freeze-on of cold water could both potentially lead to a till-water-ice mixture. The occurrence of water as well as ice could be explained by inhibited regelation due to small passages for the former mechanism and differences in the local pressure-melting point for the latter.

\section{Erosional and depositional processes}

The till thicknesses of 4.5 and $7.5 \mathrm{~m}$ suggest a depositional environment, unless erosion is occurring underneath the till layer. Erosion of bedrock by a till layer has been modeled by Cuffey and Alley (1996) and Hindmarsh (1996), who found that erosion under a till layer will not happen unless basal motion is very high or the substrate very weak. Tulaczyk (1998) treats subglacial till as a plastic material containing clasts. He predicts the existence of discrete shear zones, which can change position due to water-pressure fluctuations that diffuse into the till layer. He concludes that a diurnal water-pressure variation of $10 \mathrm{kPa}$ amplitude would affect a till with a hydraulic diffusivity of about $10^{-6} \mathrm{~m}^{2} \mathrm{~s}^{-1}$ to a depth of about $0.3 \mathrm{~m}$. Consolidation tests on Black Rapids Glacier till show a hydraulic diffusivity of about $10^{-6} \mathrm{~m}^{2} \mathrm{~s}^{-1}$. If seasonal variations are taken into account, the pressure variation and therefore the weak zone can diffuse to the bottom of a $7.5 \mathrm{~m}$ thick layer. It is therefore plausible that the whole layer is active and that erosion is happening, intermittently, at the base of the active till beneath Black Rapids Glacier. This conclusion holds true even if the hydraulic diffusivity is almost an order of magnitude lower. A lower diffusivity should be expected in the uppermost ice-bearing till, because the above-mentioned tests were done on unfrozen samples.

If there is no erosion beneath the till layer, then the drill site must be situated in a depositional environment. It is possible, however, that deposition is a sporadic process, as discussed by Iverson and Semmens (1995). They showed that changes in the effective pressure and in the sliding speed can change subglacial conditions from regelation into basal till to melt-out of basal debris. Regelation and melt-out (deposition) are competitive effects. Because melt-out is a function of the basal shear stress and basal motion, and regelation is a function of the effective pressure, it is possible that deposition happens only at times of low effective pressures and high basal speeds (high melt rate), as in early summer or under surge conditions. If massive melt-out took place during a surge, one would expect debris to accumulate in basal ice under quiescent conditions. The basal ice is relatively clean, however. This argues against such a cycle, and the scenario of erosion occurring underneath a till layer would therefore seem more likely. Note also that the presence of ice near the top of the till layer indicates that melt-out and deposition are not taking place, at least during sampling.

The lithology of the till clasts indicates that the erosional source is $\leq 2 \mathrm{~km}$ upstream of the drilling site, above which point the glacier bends to the south and overlies different bedrock, south of the Denali Fault. Only 14\% of the recovered clasts were derived from that area. These could have been derived supraglacially, although some rounding was observed, suggesting contact with a basal traction zone. The vast majority of the clasts are therefore of local origin and were eroded from the bed, since the $2 \mathrm{~km}$ distance would not be enough to transport surficial debris to the bed. The moderate rounding of clasts and the relatively coarse till matrix also suggest that the transport distance of the till is not very long (Haldorsen, 1981; Hooke and Iverson, 1995). Clasts of boulder size were encountered in the till. They indicate that plucking occurs upstream of the drill site (Röthlisberger and Iken, 1981; Hallet, 1996). The lithological diversity of the recovered clasts indicates that the bed upstream of the drill sites must be relatively inhomogeneous, reflecting the diversity of the bedrock around the glacier.

\section{Debris layers in basal ice}

Basal debris layers, separated by clean ice, occurred as high as $12 \mathrm{~m}$ above the bed. Lawson and Kulla (1978) and Strasser and others (1996) made a similar finding at Matanuska Glacier, Alaska. Their isotopic study suggests that the ice was refrozen meltwater, at least partially surface-derived. Boulton (1979) suggested that basal debris layers can form as a result of the three-dimensional flow around bedrock bumps. However, we drilled into an area of massive till and do not believe that bedrock was exposed to the ice near the drilling site. The debris encountered in our cores does not 
look surficial, because its lithology is similar to that of the underlying bedrock and because it shows signs of abrasion and crushing. Some of the layers closer to the ice till interface are steeply inclined (up to $60^{\circ}$ ) mud layers that could have formed by filling in basal cracks. Such layers would rotate to a dip of $30^{\circ}$ dipping layer in about 3 years under the strain rates expected. If the basal ice is deforming under simple shear, these layers must be fairly fresh. Alternatively, thrust faults could explain the debris layers (e.g. Rabus and Echelmeyer, 1997).

\section{Implications for surge behavior}

The possible instability of a till-water-ice mixture discussed above could relate to surge behavior. However, we have sampled such a till at only one location and it could be a very local phenomenon.

The most striking result of the drilling is the thickness of the till layer encountered, suggesting large erosion rates, either now or in the past. Humphrey and Raymond (1994) observed erosion rates of $0.3 \mathrm{~m}$ of bedrock in 20 years on Variegated Glacier. About two-thirds of the sediment evacuation occurred in the 2 years of the surge, and the bulk in probably only 2 months. Black Rapids Glacier last surged in 1936-37, when a significant amount of erosion could have happened in a similar manner. In both cases, however, it is unclear whether the high erosion rates are a prerequisite or a consequence of the surge behavior.

\section{SUMMARY}

We have shown that a commercial wireline drill rig is capable of drilling in a subglacial environment under an ice thickness of up to $600 \mathrm{~m}$. The problem of basal motion can be overcome by drilling early in the season and by reducing the drilling time to a minimum. Early-season drilling also ensures a more solid working surface, when we could move the drill rig across the glacier. There are substantial difficulties in sampling subglacial till. A combined punch corer/rotary drill would probably be an ideal combination for this task, but cobbles the size of the core diameter make the use of such a system difficult. Water for cooling and flushing must be used judiciously: too much of it will wash out all the fine material, and too little will eventually cause melting of the drill bit. Successfully latching the inner tube to the core barrel presented a problem never quite solved. As our experiences have shown, drilling and sampling subglacial till is as much an art as it is a science, even for commercial drillers.

Bedrock was recovered at two sites. Nl lies within the Denali Fault zone, while Center may be a tectonic sliver that is not exposed on either side of the glacier. The tectonic shear zone is at least $300 \mathrm{~m}$ wide, possibly as much as $1 \mathrm{~km}$. The peculiar setting of the glacier, which crosses the fault about $2 \mathrm{~km}$ upstream of the drilling site, allows us to make some conclusions about the origin of the till.

A till layer of $7.5 \mathrm{~m}$ at $\mathrm{Nl}$ and $4.5 \mathrm{~m}$ at Center was encountered, confirming the predictions of Nolan and Echelmeyer (1999a, b). The till is of local ( $<2 \mathrm{~km}$ upstream) origin, only $14 \%$ of the clasts originating south of the fault. The degree of rounding indicates a certain amount of travel in the basal zone. Ice-bearing till was sampled near the top of the till layer $(\leq 1.2 \mathrm{~m}$ below the ice-till interface). This ice could have been formed by regelation or freezing of cold water. The till contains at least $20 \%$ of clasts that are pebble size and larger. The till matrix is mostly sandy with a very low clay and silt fraction. The water content of samples just below the interface is $20-30 \%$, much higher than the liquid limit, suggesting the presence of ice. Such a till-water-ice mixture is potentially unstable.

Debris layers in basal ice were encountered as far as $12 \mathrm{~m}$ above the ice-till interface. Immediately above the interface at $\mathrm{Nl}$, steeply inclined mud dikes were sampled. They represent either flow along shear planes or recently filled-in basal cracks.

\section{ACKNOWLEDGEMENTS}

The fieldwork described in this paper was an order of magnitude larger than that which we normally encounter on valley glaciers. It would have been impossible without the help of many field assistants and helpers. We want to thank A. Harrison for a wonderful job as a cook and morale upkeeper, the drillers and drill helpers of Elgin Exploration Co., Calgary, Canada, and D. Pomraning, J. Collins, L. Sombardier, R. Wilson, O. Eisen, H. Engelhardt, I. Willis, M. Nolan and D. Elsberg. The Polar Ice Coring Office did the drill contracting. Two reviewers provided valuable comments. This work was supported by U.S. National Science Foundation grant OPP 9423477.

\section{REFERENCES}

Bearth, P. 1953. Zermatt. Zürich, Orell Füssli, Schweizerische Geologische Kommission. Geologischer Atlas der Schweiz. Atlasblatt 29, scale $1: 25000$.)

Blake, E.W. and G. K. C. Clarke. 1991. Correspondence. Subglacial water and sediment samplers. J. Glaciol., 37(125), 188- 190.

Blake, E., G. K. C. Clarke and M. C. Gérin. 1992. Tools for examining subglacial bed deformation. J. Glaciol., 38(130), 388-396.

Blake, E.W., U. H. Fischer and G. K. C. Clarke. 1994. Direct measurement of sliding at the glacier bed. f. Glaciol., 40 (136), 595-599.

Boulton, G. S. 1979. Processes of glacier erosion on different substrata. J. Glaciol., 23 (89), 15-38.

Boulton, G. S. and R. C. A. Hindmarsh. 1987. Sediment deformation beneath glaciers: rheology and geological consequences, J. Geophys. Res., 92 (B9), $9059-9082$.

Bowles, J. E. 1992. Engineering properties of soils and their measurement. Fourth edition. New York, McGraw-Hill Inc.

Cochran, O. D. 1995. The subglacial hydraulics of the surge-type Black Rapids Glacier, Alaska: a schematic model. (M.Sc. thesis, University of Alaska Fairbanks.)

Cuffey, K. and R. B. Alley. 1996. Is erosion by deforming subglacial sediments significant? (Toward till continuity). Ann. Glaciol., 22, 17-24.

Drake, L. D. and R. L. Shreve. 1973. Pressure melting and regelation of ice by round wires. Proc. R. Soc. London, Ser. A, 332 (1588), 51-83.

Engelhardt, H. F., W. D. Harrison and B. Kamb. 1978. Basal sliding and conditions at the glacier bed as revealed by bore-hole photography. $\mathcal{J}$. Glaciol., 20 (84), 469-508.

Engelhardt, H., N. Humphrey, B. Kamb and M. Fahnestock. 1990. Physical conditions at the base of a fast moving Antarctic ice stream. Science, $248(4951), 57-59$.

Everett, D. H. 1961. The thermodynamics of frost damage to porous solids. Trans. Faraday Soc., 57 (9), 1541-1551.

Fischer, U. H. and G. K. C. Clarke. 1994. Ploughing of subglacial sediment. j. Glaciol., 40 (134), 97-106.

Gades, A. M. 1998. Spatial and temporal variations of basal conditions beneath glaciers and ice sheets inferred from radio echo soundings. Ph.D. thesis, University of Washington.)

Haldorsen, S. 1981. Grain-size distribution of subglacial till and its relation to glacial crushing and abrasion. Boreas, 10 (1), 91-105.

Hallet, B. 1996. Glacial quarrying: a simple theoretical model. Ann. Glaciol., $22,1-8$.

Hamilton, G. S. and J. A. Dowdeswell. 1996. Controls on glacier surging in Svalbard. f. Glaciol., $42(140)$, 157-168.

Hance, J. H. 1937. The recent advance of Black Rapids Glacier, Alaska. 7 . 
Geol., $45(64), 775-783$.

Harrison, W. D. and B. Kamb. 1973. Glacier bore-hole photography. J. Glaciol., 12 (64), 129-137.

Harrison, W. D., L. R. Mayo and D. C. Trabant. 1975. Temperature measurements on Black Rapids Glacier, Alaska, 1973. In Weller, G. and S. A. Bowling, eds. Climate of the Arctic. Fairbanks, AK, University of Alaska. Geophysical Institute, $350-352$.

Heinrichs, T. A., L. R. Mayo, K. A. Echelmeyer and W. D. Harrison. 1996. Quiescent-phase evolution of a surge-type glacier: Black Rapids Glacier, Alaska, U.S.A. J. Glaciol., 42 (140), 110-122.

Hindmarsh, R. C. A. 1996. Sliding of till over bedrock: scratching, polishing, comminution and kinematic-wave theory. Ann. Glaciol., 22, 41-47.

Hooke, R. LeB. and N. R. Iverson. 1995. Grain-size distribution in deforming subglacial tills: role of grain fracture. Geolog), 23(1), 57-60.

Hooke, R. LeB., B. Hanson, N. R. Iverson, P. Jansson and U. H. Fischer. 1997. Rheology of till beneath Storglaciären, Sweden. \%. Glaciol., $43(143), 172-179$.

Humphrey, N. F. and C. F. Raymond. 1994. Hydrology, erosion and sediment production in a surging glacier: Variegated Glacier, Alaska, 1982-83. 7. Glaciol., 40 (136), 539-552.

Humphrey, N., B. Kamb, M. Fahnestock and H. Engelhardt. 1993. Characteristics of the bed of the lower Columbia Glacier, Alaska. 7. Geophys. Res., $98(\mathrm{Bl}), 837-846$.

Iken, A. and M. Truffer. 1997. The relationship between subglacial water pressure and velocity of Findelengletscher, Switzerland, during its advance and retreat. f. Glaciol., 43 (144), $328-338$.

Iken, A., K. Echelmeyer and W. D. Harrison. 1989. A light-weight hot water drill for large depth: experiences with drilling on Jakobshavns glacier, Greenland. In Rado, C, and D. Beaudoing, eds. Ice core drilling. Proceedings of the Third International Workshop on Ice Drilling Technology, Grenoble - France, 10 14 October 1988. Grenoble, Centre National de la Recherche Scientifique. Laboratoire de Glaciologie et Géophysique de l'Environnement, 123-136.

Iverson. N. R. and D. J. Semmens. 1995. Intrusion of ice into porous media by regelation: a mechanism of sediment entrainment by glaciers. f. Geophys. Res., 100 (B7), 10,219-10,230.

Iverson, N. R., P. Jansson and R. LeB. Hooke. 1994. In-situ measurement of the strength of deforming subglacial till. f. Glaciol., 40 (136), 497-503.

Jiao Keqin, Zheng Benxing and Ma Qiuhua. 1989. Particle composition of glacial deposits in the West Kunlun Mountains. Bull. Glacier Res. 7, 153-159.

Kamb, B. 1991. Rheological nonlinearity and flow instability in the deforming bed mechanism of ice stream motion. 7. Geophys. Res., 96 (B10), $16,585-16,595$.

Lambe, T.W. and R.V. Whitman. 1979. Soil mechanics. New York, etc., John Wiley and Sons.

Lawson, D. E. and J. B. Kulla. 1978. An oxygen isotope investigation of the origin of the basal zone of the Matanuska Glacier, Alaska. J. Geol., 86 6), $673-685$.

Nokleberg, W. J. and 6 others. 1992. Preliminary geologic map of the Mount Hayes quadrangle, eastern Alaska Range, Alaska. Scale 1:250 000. U.S. Geol. Surv. Open File Rep. 92-594.

Nokleberg, W. J., G. Plafker and F. H. Wilson. 1994. Geology of south-central Alaska. In Plafker, G. and H. C. Berg, eds. The geology of Alaska.
Boulder, CO, Geological Society of America, 311-366. (The Geology of North America G-1.

Nolan, M. and K. Echelmeyer. 1999a. Seismic detection of transient changes beneath Black Rapids Glacier, Alaska, U.S.A.: I. Techniques and observations. F. Glaciol., 45(149), 119-131.

Nolan, M. and K. Echelmeyer. 1999b. Seismic detection of transient changes beneath Black Rapids Glacier, Alaska, U.S.A.: II. Basal morphology and processes. f. Glaciol., 45 (149), $132-146$.

Paterson, W. S. B. 1994. The physics of glaciers. Third edition. Oxford, etc., Elsevier. Plafker, G., L. M. Gilpin and J. C. Lahr. 1994. Plate 12. Neotectonic map of Alaska. Scale 1:2500 000. In Plafker, G. and H. C. Berg, eds. The geology of Alaska. Boulder, CO, Geological Society of America. (In accompanying slipcase.) (The Geology of North America G-1.

Post, A. 1969. Distribution of surging glaciers in North America. f. Glaciol., 8(53), 229-240.

Rabus, B.T. and K. A. Echelmeyer. 1997. The flow of a polythermal glacier: McCall Glacier, Alaska, U.S.A. 7. Glaciol., 43 145), $522-536$.

Raymond, C. F., R. J. Benedict, W. D. Harrison, K. A. Echelmeyer and M. Sturm. 1995. Hydrological discharges and motion of Fels and Black Rapids Glaciers, Alaska, U.S.A.: implications for the structure of their drainage systems. J. Glaciol., 41 (138), 290-304.

Reger, R. D., A. G. Sturmann andJ. E. Beget. 1993. Dating Holocene moraines of Black Rapids Glacier. Delta River valley, central Alaska Range. In Solie, D. N. and F. Tannian, eds. Short notes on Alaskan geology 1993. Fairbanks, AK, Alaska Division of Geological and Geophysical Surveys, 51-59. (Professional Report 113.).

Robin, G. de Q. 1976. Is the basal ice of a temperate glacier at the pressure melting point? f. Glaciol., 16 74), $183-196$.

Röthlisberger, H. 1968. Erosive processes which are likely to accentuate or reduce the bottom relief of valley glaciers. International Association of Scientific Hydrology Publication 79 (General Assembly of Bern 1967-Snow and Ice), 87-97.

Röthlisberger, H. and A. Iken. 1981. Plucking as an effect of water-pressure variations at the glacier bed. Ann. Glaciol., 2, 57-62.

Strasser, J. C., D. E. Lawson, G.J. Larson, E. B. Evenson and R. B. Alley. 1996. Preliminary results of tritium analyses in basal ice, Matanuska Glacier, Alaska, U.S.A.: evidence for subglacial ice accretion. Ann. Glaciol., 22, 126-133.

Sturm, M. and D. M. Cosgrove. 1990. Correspondence. An unusual jökulhlaup involving potholes on Black Rapids Glacier, Alaska Range, Alaska, U.S.A. J. Glaciol., $36(122), 125-126$.

Tulaczyk, S. In press. Ice sliding over weak, fine-grained tills: dependence of ice till interactions on till granulometry. In Mickelson, D. M. and J.V. Attig, eds. Glacial processes: past and present. Boulder, CO, Geological Society of America.

Tulaczyk, S., B. Kamb, R. P. Scherer and H. F. Engelhardt. 1998. Sedimentary processes at the base of the West Antarctic ice stream: constraints from textural and compositional properties of subglacial debris. J. Sediment. Res., 68 (3A), 487-496.

Wilbur, S.W. 1988. Surging versus non-surging glaciers: a comparison using morphometry and balance. (M.Sc. thesis, University of Alaska Fairbanks.

MS received 15 September 1998 and accepted in revised form 4 March 1999 